\title{
Therapeutic Potential of Canine Bone Marrow Derived Mesenchymal Stem Cells and its Conditioned Media in Diabetic Rat Wound Healing
}

\section{Mohd Matin Ansari', Sreekumar TR¹, Vikash Chandra ${ }^{1 *}$, Pawan K Dubey ${ }^{1}$, G Sai Kumar ${ }^{2}$, Amarpal $^{3}$ and G Taru Sharma ${ }^{1}$}

${ }^{1}$ Reproductive Physiology Laboratory, Division of Physiology and Climatology, Indian Veterinary Research Institute Izatnagar -243 122 (UP), India ${ }^{2}$ Division of Veterinary Pathology, 3Division of Veterinary Pathology, Indian Veterinary Research Institute Izatnagar -243 122 (UP), India ${ }^{3}$ Division of Veterinary Surgery, Indian Veterinary Research Institute Izatnagar -243 122 (UP), India

\begin{abstract}
Present study was conducted to explore the possibility of treating the diabetic rat wounds by canine bone marrow derived mesenchymal stem cells (BMSCs) and its conditioned media (CM). Canine bone marrow stem cells were isolated ascetically from dog and cultured in vitro. Stem cells conditioned media was collected from third passage cells at 120 hours of culture. Streptozotocin was used for induction of diabetes in rats. Six groups were made for the wound healing therapy in which group I, II and III were non-diabetic while group IV, V and VI were diabetic with six animals in each group and one wound was created in each animal. Group II and V received stem cells in culture media and group III and VI received conditioned media while group I and IV were kept as respective controls given only stem cell culture media. Stem cells and its conditioned media were injected at the periphery of wounds. Wound healing was assessed by wound contraction, photographic evaluation at different time interval $\left(0,3^{\text {rd }}, 7^{\text {th }}, 14^{\text {th }}, 21^{\text {st }}\right.$ and $28^{\text {th }}$ day) and histomorphological examination on day 28 . The outcomes of wound healing experiment suggested that canine bone marrow stem cells as well as its conditioned media can be exploited xenogenically very well for diabetic rat wound healing.
\end{abstract}

Keywords: Xenogenic; Conditioned media; Canine MSCs; Diabetic rat 24 wound healing; Stem cell therapy

\section{Introduction}

Wound healing is a complex phenomenon covering four overlapping phases of wound healing mechanism i.e. inflammation, proliferation, remodeling and maturation [1]. MSCs can help in wound healing through their potential to differentiate and regenerate damaged epithelium through differentiation and fusion [2]. MSCs can be potentially used for allogenic as well as autologous transplantation [3], because they express intermediate levels of MHC Class I antigens and negligible levels of MHC Class II antigens, as do differentiated MSC derivatives [4]. In diabetes mellitus, wound remain in a chronic inflammatory state and fail to heal in a timely and orderly manner. The sequence of cellular and molecular events, are disturbed in diabetes resulting impaired wound healing. MSCs improve healing of diabetic wounds in rats and significantly increase collagen levels in diabetic wounds and wound breaking strength [5] but the mechanisms of impaired wound healing in diabetes are not completely understood. The function of neutrophils and macrophages, including cell adherence, chemotaxis, phagocytosis, cytokine production and secretion are inhibited in diabetes [6,7]. Stem cell application is a new hope to treat difficult to heal wounds or chronic wounds [8] as diabetic wounds. Transplanted BMSCs could be retained at the wound sites during the healing process and subsequently promote wound healing through angiogenesis [9]. MSC conditioned (MSC-CM) media having a variety of growth factors; cytokines etc. acts as chemo-attractant and recruiting macrophages and endothelial cells for the wound healing. BMSC-CM has same effect as MSC on wound healing with accelerated epithelialization [10]. Though earlier reports indicates that both MSCs improve wound healing in diabetes but there is no report on effect 47 of mesenchymal stem cell conditioned media in diabetic rat wound healing. Present experiment intended to evaluate the potential of canine BMSCs and BMSC-CM for the quality wound healing in rats.

\section{Materials and Methods}

Isolation and culture of canine bone marrow mesenchymal stem cells (cBMSC)

The bone marrow was collected from the iliac crest of canine and nucleated cells were isolated with a Ficoll density gradient method. Nucleated cells were cultured in Dulbecco's Modified Eagle's Medium (DMEM; Sigma) supplemented with 15\% fetal bovine serum (FBS) in 24 well tissue culture plate (Nunc). Well characterized third passage plastic adherent Mesenchymal stem cells (data not shown) were used for experimentation.

\section{Collection of stem cell conditioned media (CM)}

BMSCs (3rd passage) were cultured up to $80-90 \%$ confluence in 24 well plates and media was changed with fresh culture medium. CM was collected at 120 hours of culture and centrifuged at $1000 \mathrm{rpm}$ at $4^{\circ} \mathrm{C}$ for 5 minutes and stored at $-20^{\circ} \mathrm{C}$. For stem cell treatment, dose was prepared in normal stem cell culture media $\left(2 \times 10^{5}\right.$ cells per dose).

\section{Animals}

Thirty six clinically healthy wister rats were used in this study. After a week of acclimatization, rats were randomly divided into six groups having six animals each. The animals were provided standard

*Corresponding author: Vikash Chandra, Reproductive Physiology Laboratory Division of Physiology and Climatology, Indian Veterinary Research Institute Izatnagar-243 122 (UP), India, E-mail: vikashvet15@gmail.com

Received June 25, 2013; Accepted July 17, 2013; Published July 19, 2013

Citation: Ansari MM, Sreekumar TR, Chandra V, Dubey PK, Kumar GS, et al (2013) Therapeutic Potential of Canine Bone Marrow Derived Mesenchymal Stem Cells and its Conditioned Media in Diabetic Rat Wound Healing. J Stem Cell Res Ther 3: 141. doi:10.4172/2157-7633.1000141

Copyright: (c) 2013 Ansari MM, et al. This is an open-access article distributed under the terms of the Creative Commons Attribution License, which permits unrestricted use, distribution, and reproduction in any medium, provided the original author and source are credited. 
Citation: Ansari MM, Sreekumar TR, Chandra V, Dubey PK, Kumar GS, et al. (2013) Therapeutic Potential of Canine Bone Marrow Derived Mesenchymal Stem Cells and its Conditioned Media in Diabetic Rat Wound Healing. J Stem Cell Res Ther 3: 141. doi:10.4172/21577633.1000141

Page 2 of 6

diet and water ad libitum and maintained under uniform management conditions.

\section{Diabetes induction}

Diabetes in rats was induced by intra-peritonial (i/p) administration of Streptozotocin $(60 \mathrm{mg} / \mathrm{Kgb} . w \mathrm{t}$.) in freshly prepared citrate buffer with $\mathrm{pH}$ 4.5. Blood sugar level was recorded using Accu Check glucometer before and after administration of Streptozotocin (Normal blood sugar level recorded $80-100 \mathrm{mg} / \mathrm{dl})$. Rats with blood sugar level more than $70280 \mathrm{mg} / \mathrm{dl}$ (Figure 2) and signs of polydipsia and ketonuria were considered as diabetic [11]. After sacrificing the rats, pancreas was collected in $3.7 \%$ buffered formalin for fixing. Pancreatic tissue was then embedded in paraffin, sectioned it using microtome, stained with Haematoxylin and Eosin and mounted in neutral DPX medium and examined under light microscope.

\section{Wound creation and animal experimentation}

Animals were kept off fed for 6 hours and given water ad lib before surgery. Wound creation was done aseptically under general anesthesia (xylazine $5 \mathrm{mg} / \mathrm{kg}$ followed by ketamine $50 \mathrm{mg} / \mathrm{kg}$ ). One $\left(20 \times 20 \mathrm{~mm}^{2}\right)$ full thickness excision skin wound on dorsal area was created to each animal. All the animals were housed in individual cages and administered with broad spectrum antibiotic for five consecutive days. Group I, II and III were non-diabetic while group IV, V and VI were diabetic with six animals in each group (Table 1). Group II and $\mathrm{V}$ received stem cells $\left(2 \times 10^{5}\right.$ per dose) in culture media and group III and VI received conditioned media ( $1 \mathrm{ml}$ dose) while group I and IV were kept as respective controls given only stem cell culture media ( $1 \mathrm{ml}$ dose). Stem cells and its conditioned media were injected at the periphery of wounds. Treatment was given on day $0,3^{\text {rd }}, 7^{\text {th }}, 14^{\text {th }}$ and $21^{\text {st }}$ post surgery and simultaneously wound healing parameters were observed. Animals were euthanized on day $28^{\text {th }}$ post surgery and histopathology samples of skin and pancrease were taken for respective studies.

\section{Assessment of wound healing}

Wound area was recorded by tracing the wound margins on the transparent sheets with graph paper (on $0,3^{\text {rd }}, 7^{\text {th }}, 14^{\text {th }}, 21^{\text {st }}$ and $28^{\text {th }}$

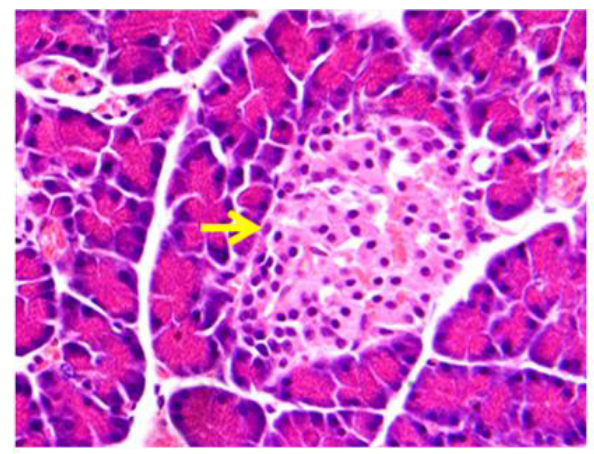

Fig.1(a). Non-diabetic animals, presence of normal islet cells.

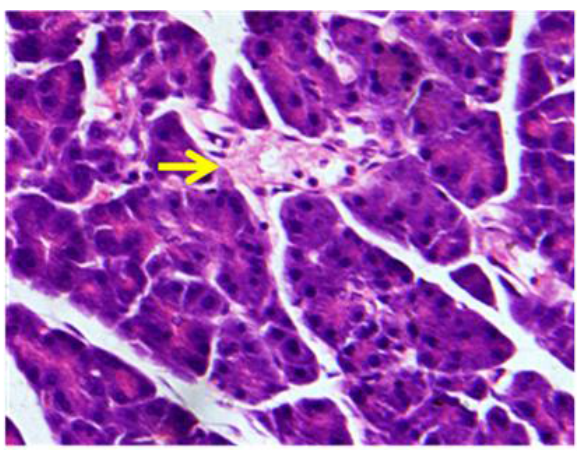

Fig.1(b). Diabetic animals, degranulated islet cells and constriction of cytoplasm.

Figure 1: Histomorphology of pancrease.

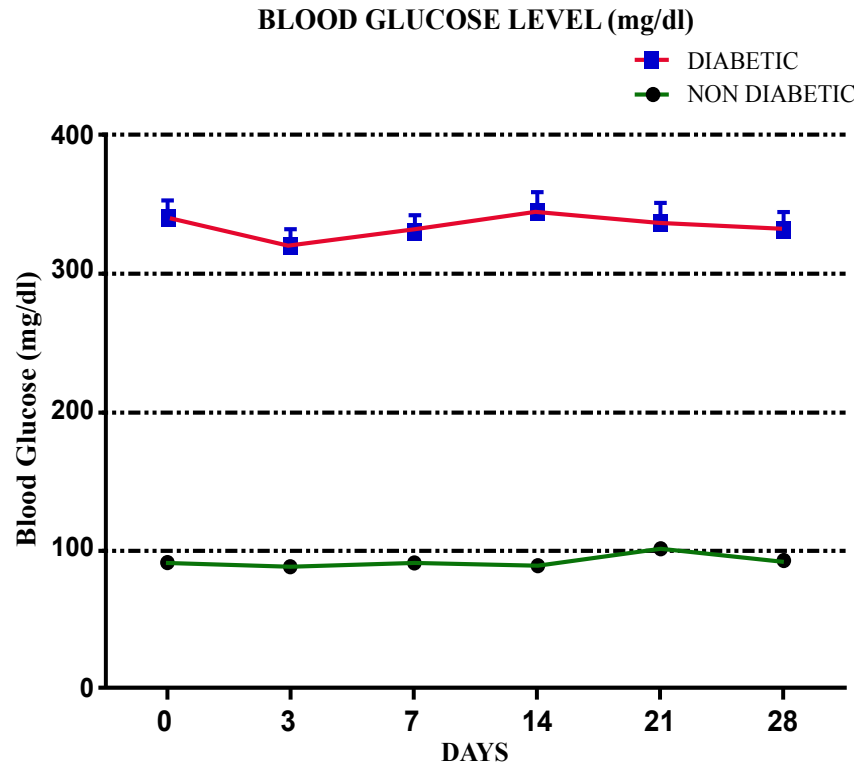

Figure 2: Blood glucose level in non-diabetic and diabetic rats. 
Citation: Ansari MM, Sreekumar TR, Chandra V, Dubey PK, Kumar GS, et al. (2013) Therapeutic Potential of Canine Bone Marrow Derived Mesenchymal Stem Cells and its Conditioned Media in Diabetic Rat Wound Healing. J Stem Cell Res Ther 3: 141. doi:10.4172/21577633.1000141

Page 3 of 6

\begin{tabular}{|c|c|c|c|}
\hline Group & Treatment & Healthy animals (no.) & Group \\
\hline I & Control ND & 6 & IV Control D \\
\hline II & BMSC-CM ND & 6 & V BMSC-CM D \\
\hline III & BMSC ND & 6 & VI BMSC D \\
\hline
\end{tabular}

Table 1: Experimental design for the xenogenic transplantation of canine BMSCs and its conditioned media in diabetic rat model for wound healing

\begin{tabular}{|c|c|c|c|c|c|c|}
\hline Group & 0 Day & $3^{\text {rd }}$ DAY & $7^{\text {th }}$ DAY & $14^{\text {th }} \mathrm{DAY}$ & $21^{\text {st }}$ DAY & $28^{\text {th }}$ DAY \\
\hline Nondiabetic & $91.4 \pm 2.6^{a}$ & $87.3 \pm 1.9^{a}$ & $90.8 \pm 2.3^{a}$ & $88.9 \pm 2.2^{\mathrm{a}}$ & $101.2 \pm 2.6^{a}$ & $92.3 \pm 2.5^{\mathrm{a}}$ \\
\hline Diabetic & $339.4 \pm 14.1^{b}$ & $320.4 \pm 11.3^{b}$ & $330.3 \pm 12.2^{b}$ & $344.8 \pm 14.0^{b}$ & $336.6 \pm 14.2^{b}$ & $331.7 \pm 12.5^{b}$ \\
\hline
\end{tabular}

Values (mean $\pm \mathrm{SE})$ in the column bearing different superscripts differ significantly $(p<0.05)$

Table 2: Blood glucose level $(\mathrm{mg} / \mathrm{dl})$ at different time interval.

day post surgery) and wound contraction was measured by a rate of wound reduction, as well as percent reduction in wound area. Independent observers to assess the quality of wound healing and cosmetic outcomes evaluated weekly photographs. The haematoxylin and eosin stained tissue sections were evaluated microscopically using the histological scoring system described by Borena et al. [12]. Epithelialization was scored from 1 to 4 representing most similar to normal skin to least similarity to normal skin. Neovascularization was scored as 1 resembling normal skin (0-1 new blood vessels), 2 Mild (2-5 blood vessels), 3 Moderate (6-10 blood vessels) or 4 Severe ( $>10$ blood vessels). Collagen fibre arrangement was graded as, 1 best arranged, 2 better arranged, 3 worse arranged and 4 worst arranged, collagen fibre density was graded as 1 denser, 2 dense and 3 less dense, while collagen fibre thickness was graded as 1, thicker, 2 thick and 3 thin.

\section{Statistical Analysis}

The means of different parameters were analyzed by one way ANOVA as per the procedure described by Snedecor and Cochran [13].

\section{Results}

\section{Wound healing evaluation}

Macroscopical evaluation: Non-diabetic wounds healed by $21^{\text {st }}$ day while diabetic treated wounds healed by $28^{\text {th }}$ day. But in both non-diabetic and diabetic groups the BMSCs and CM increased the wound healing rate compared to control groups. It has been found that the rates of hair growth in diabetic rats were reduced compared to non-diabetic groups. From the day of surgery there was significant difference between wound size of non-diabetic and diabetic group due to loose skin of diabetic animals. The diabetic wounds were larger in size and up to $7^{\text {th }}$ day of treatment, there was no difference in rate of wound healing within group of non-diabetic and diabetic animals. On $14^{\text {th }}$ day post surgery, among the treatment the BMSC-CM and BMSC showed a significant $(\mathrm{p}<0.05)$ reduction in wound area than those treated with freshly prepared media (Figure 3 and Table 3). On day $21^{\text {st }}$ all non-diabetic treated wounds were healed. However the diabetic treatment groups were healed by day $28^{\text {th }}$. On day $21^{\text {st }}$, the mean per cent contraction in conditioned media and stem cell treated non diabetic wounds were significantly $(\mathrm{p}<0.05)$ higher (Figure 4 ; Table $4)$. By the day 28,100 per cent contraction was recorded in all groups except diabetic control. A higher percentage of wounds were healed completely between days 21 and 28 after surgery in the treatment group whereas diabetic control group were not healed completely by 28 days post surgery.

\section{Histomorphological observations}

By day 28, BMSC treated wounds (both non-diabetic and diabetic) had significantly denser, thicker collagen fibers (indicated by lower scores) (Figure 5; Table 5). Newly created wound resulted with infiltration of polymorphonuclear cells and on day 28 post surgery these cells persisted more in diabetic groups but reduced significantly after stem cells or CM treatment (Figure 6). Collagen arrangement was significantly lower in the BMSC (non-diabetic) treated groups than in the control group (diabetic/non-diabetic), BMSC-CM (diabetic/ non-diabetic) and BMSC (diabetic) as evident from figure 6. On $28^{\text {th }}$ day epithelialization in BMSC (non-diabetic) treated wound had significantly lower score than in the control groups (diabetic/nondiabetic), BMSC CM (diabetic/non-diabetic) and BMSC (diabetic) (Table 5 and Figure 6). Groups treated with BMSC (non-diabetic), BMSC-CM (non-diabetic), BMSC (diabetic) resembled the normal neovascularization (Table 5 and Figure 6).

\section{Discussion}

MSCs have a great appeal for tissue engineering because of the ease in isolation, their high in vitro expansion potential, self-renewal capacity and multi-potentiality [14]. The present study was aimed for generating information about isolation of canine BMSCs and possibilities to treat diabetic wounds by the use of xenogenic MSCs. This study seemed to be the first to show the therapeutic potential of stem cell conditioned media for xenogenic application.

Canine Mesenchymal stem cells were successfully isolated from canine bone marrow. In vitro studies demonstrated that MSCs can secrete a variety of angiogenic, anti-apoptotic and mitogenic factors such as VEGF, hepatocyte growth factor (HGF), angiopoietin-1, adreno medullin (AM) and IGF-1 [15]. It has been proposed that MSCs act as trophic mediators in wound healing [16]. Streptozotocin is commonly used for experimental induction of type 1 diabetes mellitus, which causes selective pancreatic islet $\beta$-cell cytotoxicity mediated through the release of nitric oxide (NO). Streptozotocin by acting on mitochondria generates SOD anions which lead to the diabetic complications [17]. In the present study, we tested the therapeutic value of canine bone marrow mesenchymal stem cells and its conditioned media in cutaneous wound healing in diabetic rat model. In general, our research outcomes demonstrated not much difference among xenogenic canine stem cells and stem cell conditioned media treated wounds in terms of wound contraction rate and quality of wound healing. Furthermore, in our experiment, quality of wound healing (in terms of epithelization, neovascularization and collagen deposition characteristics) on $28^{\text {th }}$ day post surgery was found to be better in stem cell and CM groups than control groups. Kwon et al. [5] reported that allogenic stem cell treatment resulted in thicker, denser and well arranged collagen deposition in diabetic wound healing in rabbits though, did not correlated it with conditioned media (no study available regarding treatment with stem cell conditioned media). No significant difference in stem cell treatment and CM treatment may be due to treatment with 
Citation: Ansari MM, Sreekumar TR, Chandra V, Dubey PK, Kumar GS, et al. (2013) Therapeutic Potential of Canine Bone Marrow Derived Mesenchymal Stem Cells and its Conditioned Media in Diabetic Rat Wound Healing. J Stem Cell Res Ther 3: 141. doi:10.4172/21577633.1000141

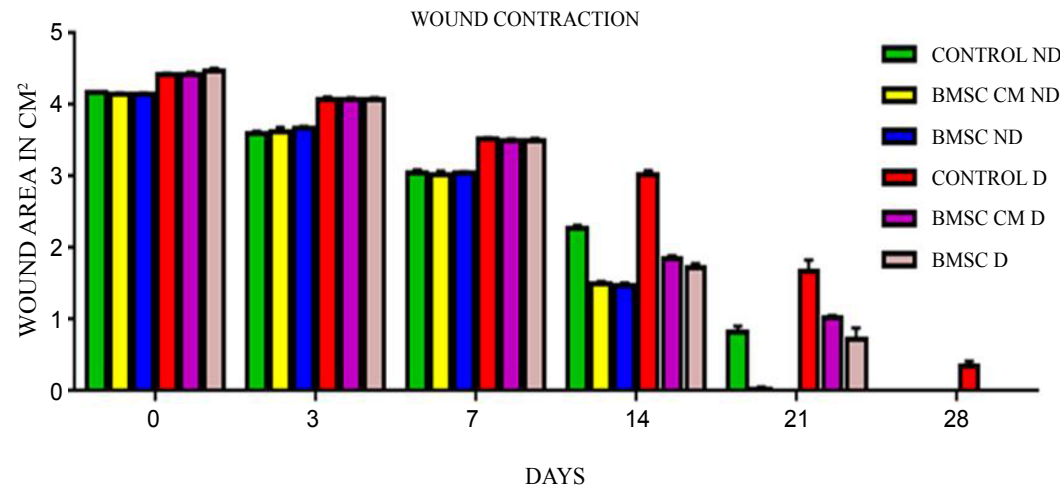

Figure 3: Rate of wound contraction in different groups

\begin{tabular}{|c|c|c|c|c|c|c|}
\hline Group & 0 Day & $3^{\text {rd }}$ DAY & $7^{\text {th }}$ DAY & $14^{\text {th }}$ DAY & $21^{\text {st }}$ DAY & $28^{\text {th }}$ DAY \\
\hline CONTROL ND & $4.17 \pm 0.02^{\mathrm{a}}$ & $3.60 \pm 0.04^{* a}$ & $3.05 \pm 0.04^{* a}$ & $2.28 \pm 0.04^{\star c} \mathrm{c}$ & $0.83 \pm 0.08^{* b}$ & $0.00 \pm 0.00^{*} a$ \\
\hline BMSC-CM ND & $4.15 \pm .02^{\mathrm{a}}$ & $3.63 \pm 0.06^{\star a}$ & $3.03 \pm 0.04^{* a}$ & $1.50 \pm 0.04^{* a}$ & $0.03 \pm 0.02^{* a}$ & $0.00 \pm 0.00^{* a}$ \\
\hline BMSC ND & $4.15 \pm 0.02^{\mathrm{a}}$ & $3.67 \pm 0.03^{\star a}$ & $3.05 \pm .02^{* a}$ & $1.48 \pm 0.03^{* a}$ & $0.00 \pm 0.00^{* a}$ & $0.00 \pm 0.00^{*} a$ \\
\hline CONTROL D & $4.42 \pm 0.03^{b}$ & $4.08 \pm 0.03^{* b}$ & $3.52 \pm 0.03^{\star b}$ & $3.03 \pm 0.05^{\star d}$ & $1.67 \pm .17^{\star \mathrm{c}}$ & $0.35 \pm 0.07^{* b}$ \\
\hline BMSC-CM D & $4.42 \pm .04^{b}$ & $4.07 \pm .03^{* b}$ & $3.50 \pm 0.03^{* b}$ & $1.85 \pm 0.04^{* b}$ & $1.01 \pm 0.04^{* b}$ & $0.00 \pm .00^{* a}$ \\
\hline BMSC D & $4.48 \pm .03^{b}$ & $4.06 \pm .03^{* b}$ & $3.50 \pm 0.03^{\star b}$ & $1.73 \pm 0.05^{\star b}$ & $0.73 \pm 0.15^{* b}$ & $0.00 \pm 0.00^{* a}$ \\
\hline
\end{tabular}

Values (mean $\pm S E$ ) in the column bearing different superscripts differ significantly $(p<0.05)$.

Table 3: Wound area in excision wounds of rats in various treatment groups at different time interval.

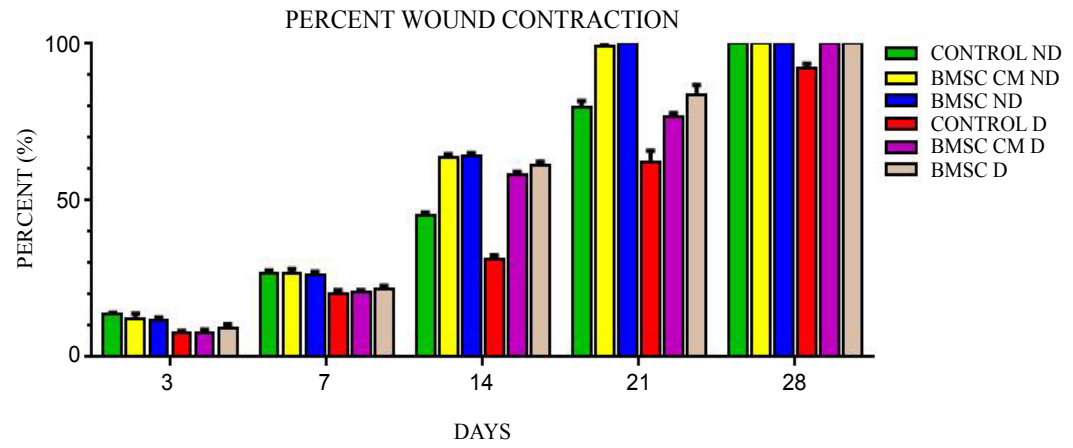

Figure 4: Mean percent wound contraction in different groups.

\begin{tabular}{|c|c|c|c|c|c|}
\hline Group & $3^{\text {rd }}$ DAY & $7^{\text {th }}$ DAY & $14^{\text {th }}$ DAY & $21^{\text {st }}$ DAY & $28^{\text {th }}$ DAY \\
\hline CONTROL ND & $13.60 \pm 0.54^{c}$ & $26.80 \pm 0.79^{* b}$ & $45.19 \pm 0.92^{* b}$ & $79.98 \pm 1.84^{* b c}$ & $100.00 \pm 0.00^{* b}$ \\
\hline BMSC-CM ND & $12.44 \pm 1.41^{\mathrm{bc}}$ & $26.88 \pm 1.33^{\star b}$ & $63.85 \pm 0.90^{* d}$ & $99.19 \pm 0.51^{\star d}$ & $100.00 \pm 0.00^{* b}$ \\
\hline BMSC ND & $11.62 \pm 1.10^{\mathrm{bc}}$ & $26.49 \pm 0.77^{\star b}$ & $64.23 \pm 0.89^{*} d$ & $100.00 \pm 0.00^{* d}$ & $100.00 \pm 0.00^{* b}$ \\
\hline CONTROL D & $7.53 \pm 0.93^{a}$ & $20.35 \pm 1.05^{\star a}$ & $31.30 \pm 1.25^{* a}$ & $62.33 \pm 3.63^{* a}$ & $92.11 \pm 1.47^{* a}$ \\
\hline BMSC-CM D & $7.89 \pm .92^{\mathrm{a}}$ & $20.73 \pm 0.77^{\star a}$ & $58.08 \pm 1.13^{* c}$ & $76.97 \pm 0.90^{* b}$ & $100.00 \pm 0.00^{* b}$ \\
\hline BMSC D & $9.25 \pm 1.28^{\mathrm{ab}}$ & $21.92 \pm 0.83^{\star a}$ & $61.33 \pm 1.05^{\star d}$ & $83.65 \pm 3.27^{\star c} \mathrm{c}$ & $100.00 \pm 0.00^{* b}$ \\
\hline
\end{tabular}

Values (mean $\pm S E)$ in the column bearing different superscripts differ significantly $(p<0.05)$.

Table 4: Percent wound contraction in excision wounds of rats in various treatment groups.

these two in small intervals (about 7 day interval). Similar results were reported in allogenic and xenogenic MSCs [18]. It has been reported that, surface epithelium of stem cell treated wounds became thinner and appeared more close to normal skin sections in comparison to PBS treated wound sections [19]. MSCs act by immune modulation and immune privileged properties [20-23]. Earlier experiments suggested that neither human nor animal MSCs express co-stimulatory antigens and thus MSCs appear to be immune-privileged [24]. In the present study, we opted both, the direct application of MSC and MSC-CM on wounds which has the potential advantage of promoting regeneration via MSC differentiation in addition to repair via MSC paracrine signaling [25]. In the current investigation it was found that the canine stem cell (BMSCs) treated groups as well as canine bone marrow stem cell conditioned media (BMSC-CM) showed significantly $(\mathrm{P}<0.05)$ 
Citation: Ansari MM, Sreekumar TR, Chandra V, Dubey PK, Kumar GS, et al. (2013) Therapeutic Potential of Canine Bone Marrow Derived Mesenchymal Stem Cells and its Conditioned Media in Diabetic Rat Wound Healing. J Stem Cell Res Ther 3: 141. doi:10.4172/21577633.1000141

Page 5 of 6

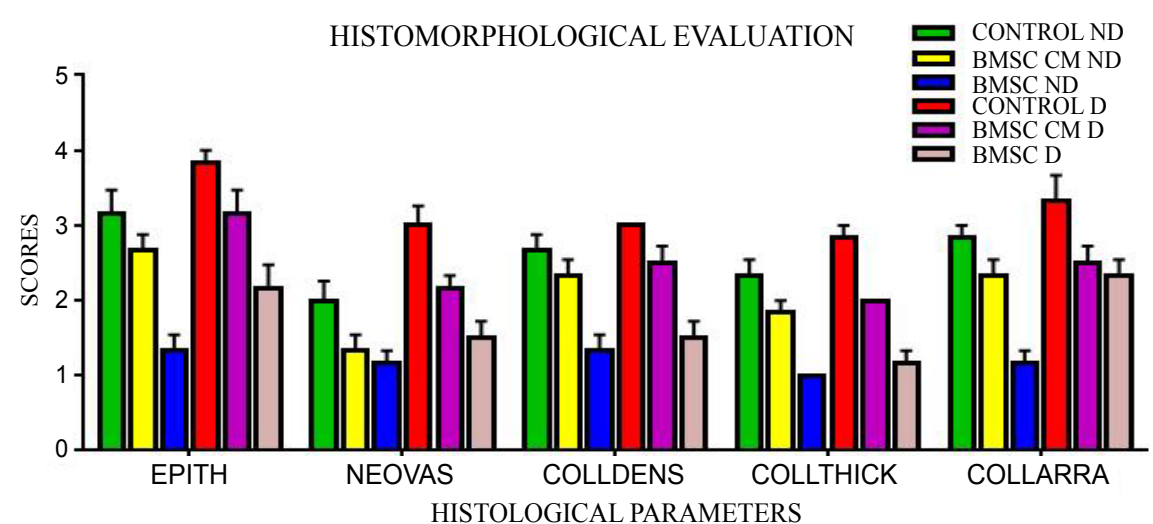

Figure 5: Scoring of Histomorphological observation of healed wound at day 28 of surgery.

\begin{tabular}{|c|c|c|c|c|c|}
\hline Group & EPITHELIA LIZATION & NEOVASCUL ARIZATION & COLLAGE N DENSITY & COLLAGEN THICKNESS & COLLAGEN ARRANGEMENT \\
\hline CONTROL ND & $3.17 \pm 0.31^{\text {cd }}$ & $2 \pm 0.26^{b c}$ & $2.67 \pm 0.21^{\mathrm{bc}}$ & $2.33 \pm 0.21^{c}$ & $2.83 \pm 0.17^{\mathrm{bc}}$ \\
\hline BMSC-CM ND & $2.67 \pm 0.21^{\mathrm{bc}}$ & $1.33 \pm 0.21^{\mathrm{a}}$ & $2.33 \pm 0.21^{\mathrm{b}}$ & $1.83 \pm 0.167^{\mathrm{b}}$ & $2.33 \pm 0.21^{\mathrm{b}}$ \\
\hline BMSC ND & $1.33 \pm 0.21^{a}$ & $1.17 \pm 0.17^{\mathrm{a}}$ & $1.33 \pm 0.21^{\mathrm{a}}$ & $1.00 \pm 0.00^{a}$ & $1.17 \pm 0.17^{\mathrm{a}}$ \\
\hline CONTROL D & $3.83 \pm 0.17^{d}$ & $3.00 \pm 0.26^{d}$ & $3.00 \pm 0.00^{\circ}$ & $2.83 \pm 0.17^{d}$ & $3.33 \pm 0.33^{c}$ \\
\hline BMSC-CM D & $3.17 \pm 0.31^{\text {cd }}$ & $2.17 \pm 0.17^{c}$ & $2.50 \pm 0.22^{\mathrm{bc}}$ & $2.00 \pm 0.00^{\mathrm{bc}}$ & $2.50 \pm 0.22^{\mathrm{b}}$ \\
\hline BMSC D & $2.17 \pm 0.31^{\mathrm{b}}$ & $1.50 \pm 0.22^{\mathrm{ab}}$ & $1.50 \pm 0.22^{\mathrm{a}}$ & $1.17 \pm 0.17^{\mathrm{a}}$ & $2.33 \pm 0.21^{b}$ \\
\hline
\end{tabular}

Values (mean $\pm S E$ ) in the column bearing different superscripts differ significantly $(p<0.05)$.

Table 5: Histomorphological evaluation of full thickness wound sections of rats in various treatment groups.

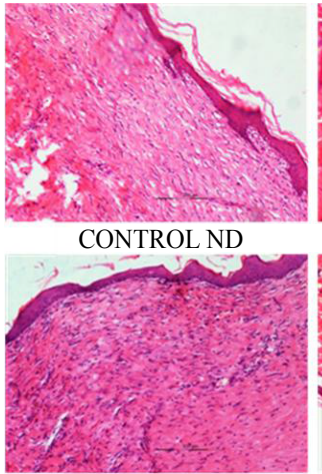

CONTROL D

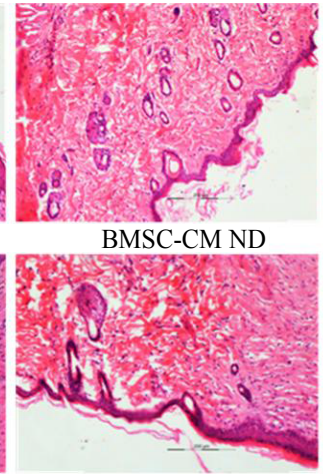

BMSC-CM D

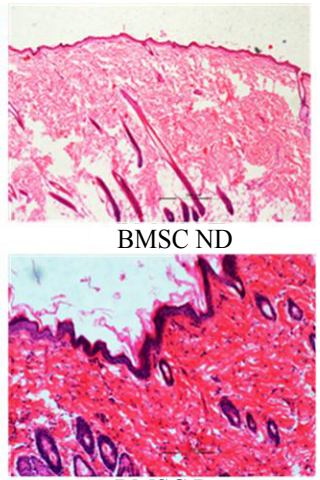

BMSC D

Figure 6: Histomorphological observation of healed skin in different groups at day 28 post surgery.

quicker rate of wound contraction. No significant difference in stem cell treatment and CM treatment may be due to small intervals (about 7 day interval) of treatments. This significant difference was well observed on 14th day post surgery. Over all our results demonstrated that there is a significant difference between diabetic and non-diabetic groups, in which diabetic group showed delayed wound healing. Earlier reports showed that mice allogenic MSCs treated group showed better wound healing compared with fibroblast [26]. Growing evidences indicate that MSCs paracrine signaling is the predominant mechanism responsible for enhanced wound repair. Supporting this statement it was reported that MSC-CM act as a chemo attractant for macrophages, endothelial cells, epidermal keratinocytes and dermal fibroblasts, implicating MSC paracrine signaling in the recruitment of these specific cell types to the wound [28]. In addition to chemotaxis, MSC paracrine signaling may also regulate cell migration in response to injury as recent data revealed that dermal fibroblasts show complete scratch wound close faster in the presence of either MSC's or MSC-conditioned medium [27]. Dermal fibroblasts secrete increased amounts of collagen type I in response to the presence of MSCs [29]. Overall, these in vitro data suggest that MSCs therapeutically applied to the wound, release soluble factors that stimulate proliferation and migration of the predominant cell types in the wound. Consequently, MSCs paracrine signaling has potential beneficial effects on angiogenesis, epithelialization, and fibroblast proliferation during wound repair. Nonetheless, there have been a number of reports suggesting that MSCs differentiate into epidermal keratinocytes, endothelial cells and pericytes in vivo [30].

The current problems with the clinical application of MSCs are insufficient engraftment of the stem cells to target tissues and inadequate vascularization of tissue engineered constructs to ensure long term viability [31]. In addition, the expression of one or more proteins specific for a certain cell lineage in vitro does not necessarily mean that MSCs bearing these proteins will exhibit the functions of this 
Citation: Ansari MM, Sreekumar TR, Chandra V, Dubey PK, Kumar GS, et al. (2013) Therapeutic Potential of Canine Bone Marrow Derived Mesenchymal Stem Cells and its Conditioned Media in Diabetic Rat Wound Healing. J Stem Cell Res Ther 3: 141. doi:10.4172/21577633.1000141

Page 6 of 6

specific cell types properly in vivo [32]. Moreover, the study by Terada et al. [33] raises doubts regarding whether in vivo trans-differentiation of transplanted MSCs actually occurs, or is the result of cell fusion misinterpreted as trans-differentiation [33,34]. Safety issues regarding the MSCs transplantation have been largely solved, particularly with autologous transplants; however, sustained curative benefit has yet not been established. It can be concluded from the present study that xenogenic Mesenchymal stem cells can be used for diabetic wound repair and more over, application of stem cell conditioned media may be one of greatest advantage in wound healing because of its ease in transport and easy application by the end users like pet owners or livestock owners.

\section{References}

1. Sumitra M, Manikandana $P$, Suguna $L$ (2005) Efficacy of Butea monosperma on dermal wound healing in rats. Int J Biochem Cell Biol 37: 566-573.

2. Wu Y, Chen L, Scott PG, Tredget EE (2007) Mesenchymal stem cells enhance wound healing through differentiation and angiogenesis. Stem Cells 25: 26482659.

3. Aggarwal SP and Pittenger MF (2005) Human mesenchymal stem cells modulate allogeneic immune cell responses. Blood 105: 1815-1822.

4. Le Blanc K, Tammik L, Sundberg B, Haynesworth SE, Ringdén O (2003) Mesenchymal stem cells inhibit and stimulate mixed lymphocyte cultures and mitogenic responses independently of the major histocompatibility complex. Scand J Immunol 57: 11-20.

5. Kwon DS, Gao X, Liu YB, Dulchavsky DS, Danyluk AL, et al. (2008) Treatment with bone marrow-derived stromal cells accelerates wound healing in diabetic rats. Int Wound J 3: 453-463.

6. Marhoffer W, Stein M, Maeser E, Federlin K (1992) Impairment of polymorphonuclear leukocyte function and metabolic control of diabetes. Diabetes Care 15: 256-260.

7. Geerlings SE, Hoepelman AI (1999) Immune dysfunction 230 in patients with diabetes mellitus (DM). FEMS Immunol Med Microbiol 26: 259-265.

8. Falanga V, Iwamoto S, Chartier M, Yufit T, Butmarc J, et al. (2007) Autologous bone marrow-derived cultured mesenchymal stem cells delivered in a fibrin spray accelerate healing in murine and human cutaneous wounds. Tissue Eng 13: 1299-1312.

9. Inoue H, Murakami T, Ajiki T, Hara M, Hoshino Y, et al. (2008) Bioimaging assessment and effect of skin wound healing using bone-marrow-derived mesenchymal stromal cells with the artificial dermis in diabetic rats. J Biomed Opt 13: 064036.

10. Chen L, Tredget EE, Wu PY, Wu Y (2008) Paracrine factors of mesenchymal stem cells recruit macrophages and endothelial lineage cells and enhance wound healing. PLoS One 3: e1886

11. Maharlooei M, Bagheri M, Solhjou Z, Jahromi B, Akrami M, et al. (2011) Adipose tissue derived mesenchymal stem cell promotes skin wound healing in diabetic rats. Diabetes Res Clin Pract 93: 228-234.

12. Borena BM, Pawde AM, Amarpal, Aithal HP, Kinjavdekar P, et al. (2009) Autologous bone marrow-derived cells for healing excisional dermal wounds of rabbits. Vet Rec 165: 563-568.

13. Snedecor GW, Cochran WG (1989) Analysis of Variance. In: Statistical Methods, 8th ed. Oxford and IBH Publishing Company, New Delhi, 562.

14. Kolf CM, Cho E, Tuan RS (2007) Biology of adult mesenchymal stem cells: regulation of niche, self-renewal and differentiation. Arthritis Res Ther 9: 204.

15. Kinnaird T, Stabile E, Burnett MS, Shou M, Lee CW, et al. (2004) Local delivery of marrow-derived stromal cells augments collateral perfusion through paracrine mechanisms. Circulation 109: 1543-1549.

16. Caplan Al and Dennis JE (2006) Mesenchymal stem cells as trophic mediators J Cell Biochem 98: 1076-1084.

17. Arunachalam k, Parimelazhagan T (2013) Antidiabetic activityof Ficus amplissima bark extract in streptozotocin induced diabetic rats. J Ethnopharmacol 147: 302-310

18. Stoff A, Rivera AA, Sanjib Banerjee N, Moore ST, Michael Numnum T, et al (2009) Promotion of incisional wound repair by human mesenchymal stem cell transplantation. Exp Dermatol 18: 362-369.

19. Pratheesh MD, Gade NE, Katiyar AN, Dubey PK, Sharma B, et al. (2013) Isolation, culture and characterization of caprine mesenchymal stem cells derived from amniotic fluid. Res Vet Sci 94: 313-319.

20. Bartholomew A, Sturgeon C, Siatskas M, Ferrer K, McIntosh K, et al. (2002) Mesenchymal stem cells suppress lymphocyte proliferation in vitro and prolong skin graft survival in vivo. Exp Hematol 30: 42-48.

21. Di Nicola M, Carlo-Stella C, Magni M, Milanesi M, Longoni PD, et al. (2002) Human bone marrow stromal cells suppress T-lymphocyte proliferation induced by cellular or nonspecific mitogenic stimuli. Blood 99: 3838-3843.

22. Tse WT, Pendleton JD, Beyer WM, Egalka MC, Guinan EC (2003) Suppression of allogeneic T-cell proliferation by human marrow stromal cells: implications in transplantation. Transplantation 75: 389-397.

23. Krampera M, Glennie S, Dyson J, Scott D, Laylor R, et al. (2003) Bone marrow mesenchymal stem cells inhibit the response of naïve and memory antigen specific T cells to their cognate peptide. Blood 101: 3722-3729.

24. Mansilla E, Marin GH, Sturla F, Drago HE, Gil MA, et al. (2005) Human mesenchymal stem cells are tolerized by mice and improve skin and spinal cord injuries. Transplant Proc 37: 292-194.

25. Hocking AM and Gibran NS (2010) Mesenchymal stem cells: paracrine signaling and differentiation during cutaneous wound repair. Exp Cell Res 316 2213-2219.

26. McFarlin K, Gao X, Liu YB, Dulchavsky DS, Kwon D, et al. (2006) Bone marrow-derived mesenchymal stem cells accelerate wound healing in the rat. Wound Repair Regen 14: 471-478.

27. Smith AN, Willis E, Chan VT, Muffley LA, Isik FF, et al. (2010) Mesenchymal stem cells induce dermal fibroblast responses to injury. Exp Cell Res 316 48-54.

28. Lee EY, Xia Y, Kim WS, Kim MH, Kim TH, et al. (2009) Hypoxia-enhanced wound healing function of adipose-derived stem cells: increase in stem cell proliferation and up-regulation of VEGF and bFGF. Wound Repair Regen 17: 540-547.

29. Kim WS, Park BS, Sung JH, Yang JM, Park SB, et al. (2007) Wound healing effect of adipose-derived stem cells: a critical role of secretory factors on human dermal fibroblasts. J Dermatol Sci 48: 15-24.

30. Sasaki M, Abe R, Fuita Y, Ando S, Inokuma D et al. (2008) Mesenchymal stem cells are recruited into wounded skin and contribute to wound repair by transdifferentiation into multiple skin cell type. J Immunol 180: 2581-2587.

31. Rippon HJ, Bishop AE (2004) Embryonic stem cells. Cell Proli 37: 23-34.

32. Sanchez-Ramos J, Song S, Cardozo-Pelaez F, Hazzi C, Stedeford T, et al. (2000) Adult bone marrow stromal cells differentiate into neural cells in vitro. Exp Neurol 164: 247-256.

33. Terada N, Hamazaki T, Oka M (2002) Bone marrow cells adopt the phenotype of other cells by spontaneous cell fusion. Nature 416: $542-545$.

34. Ringe J, Kaps C, Schmitt B, Buscher K, Bartel J, et al. (2002) Porcine mesenchymal stem cells. Induction of distinct mesenchymal cell lineages. Cell Tissue Res 307: 321-327. 